\title{
Caring for homecare: A mixed methods analysis of the current and future role of home nurses
}

\author{
Kristel De Vliegher ${ }^{1 *}$, Anja Declercq² ${ }^{2}$ Bert Aertgeerts ${ }^{3}$, Philip Moons ${ }^{4}$ \\ From Methods in Epidemiology Symposium \\ Leuven, Belgium. 17 September 2015
}

\section{Introduction}

The financial constraints and the shift of care from the hospital to the homecare setting challenges home nursing to provide care to sicker patients than in the past, to perform more intensive and technically complex nursing activities at home, and to think about a more efficient and effective use of the current home nursing staff. A mixed-method analysis was performed to understand the impact of these evolutions in home nursing in general and on the current and future role of home nurses.

\section{Aim}

To understand the evolutions in home nursing and its impact on home nurses' activities.

\section{Method}

A mixed-methods project was established comprising: (1) In-depth interviews with 15 home nurses and 8 medical specialists, and 2 focus groups with general practitioners; (2) Development and psychometric testing of a '24-hour recall instrument for home nursing'; (3) Quantitative measurement of the activities of 2478 home nurses; and (4) In-depth interviews with 12 home nurses, 12 healthcare assistants, and 8 managers of care.

\section{Results}

(1) Technical activities are always performed in combination with more intellectual and psychosocial activities; (2) An instrument with 146 items, with a mean proportion of observed agreement of 0.94 and a mean kappa of 0.71 ; (3) The top 10 of activities performed is characterized by non-technical interventions; (4) Healthcare assistants can be an answer to the increased demand for care in home nursing.

${ }^{1}$ Wit-Gele Kruis van Vlaanderen, Brussels, Belgium

Full list of author information is available at the end of the article
Authors' details

${ }^{1}$ Wit-Gele Kruis van Vlaanderen, Brussels, Belgium. '2LUCAS, Leuven, Belgium. ${ }^{3} \mathrm{ACHG}$, Leuven, Belgium. ${ }^{4}$ Department of Public Health and Primary Care, Leuven, Belgium.

Published: 17 September 2015

doi:10.1186/2049-3258-73-S1-P43

Cite this article as: De Vliegher et al:: Caring for homecare: A mixed methods analysis of the current and future role of home nurses. Archives of Public Health 2015 73(Suppl 1):P43.
Submit your next manuscript to BioMed Central and take full advantage of:

- Convenient online submission

- Thorough peer review

- No space constraints or color figure charges

- Immediate publication on acceptance

- Inclusion in PubMed, CAS, Scopus and Google Scholar

- Research which is freely available for redistribution
() Biomed Central
C Biomed Central

(c) 2015 De Vliegher et al. This is an Open Access article distributed under the terms of the Creative Commons Attribution License (http://creativecommons.org/licenses/by/4.0), which permits unrestricted use, distribution, and reproduction in any medium, provided the original work is properly cited. The Creative Commons Public Domain Dedication waiver (http://creativecommons.org/ publicdomain/zero/1.0/) applies to the data made available in this article, unless otherwise stated. 